\title{
TEA COMMERCIALS ON SOCIAL MEDIA: A REVIEW AS A SIGN OF SOCIAL CLASS ${ }^{*}$
}

\author{
Uğur GÜNDÜZ 1, Nilüfer PEMBECİOĞLU²
}

\begin{abstract}
The modern individual tries to stick to more thematic and individualized media instead of the traditional "Social Networks" of the past and the world of 21 st century the individualized concept of the media tries to establish new cultures and new hobbies aiming to canalize their eating habits. The tea commercials are easily reached, effective and seem to be successful aiming to analyze the concept of tea in the past and present society, the paper follows both qualitative and quantitative research methodology concentrating more on the positioning of the product as a sign of social class. The paper questions if the ads refer to tea consumption at different levels of human needs and if the social settings in tea ads refer to different social classes. The paper is also questioning if these tea brands, concentrate mainly on different clusters of the society, dividing them into smaller chunks ending up with the consumption of different types of products.
\end{abstract}

Keywords: commercials, social media, social networks, tea commercials

\footnotetext{
* This work was supported by Scientific Research Projects Coordination Unit of Istanbul University Project number: 10028 - 43920 Media Literacy In The 21st Century - International Basics.

${ }^{1}$ Doç. Dr., İstanbul Üniversitesi, İletişim Fakültesi Gazetecilik Bölümü, ugunduz(at)gmail.com

${ }^{2}$ Prof. Dr., İstanbul Üniversitesi, İletişim Fakültesi Radyo TV ve Sinema Bölümü, niluferpembecioglu(at)gmail.com
} 


\title{
BİR SOSYAL SINIF GÖSTERGESI OLARAK SOSYAL MEDYADA ÇAY REKLAMLARI ÜZERINE BIR INCELEME
}

\begin{abstract}
$\ddot{O Z z}$
Modern birey, geçmişin geleneksel "Sosyal Ağları" yerine tematik ve bireyselleşmiş medyaya sadık kalmaya çalışmaktadır. 21. yüzyılın hareketlenen dünyasında, medyanın bireyselleştirilmiş konsepti diyetlerini, yemek alışkanlıklarını yeniden kurmayı amaçlayan yeni kültürler ve yeni hobiler oluşturmayı denemektedir. $\mathrm{Bu}$ bağlamda, geçmişin ve eski geleneklerin temsilcileri olmaya çalışan çay reklamları, kolayca erişilebilir, etkin ve ilk bakışta oldukça başarılı görünmektedir. Geçmişte ve günümüz toplumunda çay kavramını çözümlemeyi amaçlayan bu makale, niceliksel ve niteliksel araştırma yöntemleri çerçevesinde, ürünün sosyal sınıf işareti olarak konumlandırılmasına yoğunlaşmaktadır. Çalışma, bu reklamların toplumun farklı kesimlerindeki bireylerin gereksinimlerine yönelik olup olmadığını ve çay reklamlarındaki sosyal bağlamların toplumun farklı kesimlerini gündeme getirip getirmediğini sorgulamaktadır. Ayrıca çalışma kapsamında bu çay markalarının, toplumu kendi ürettikleri farklı ürünlere yönelik farklı beslenme ve tüketim biçimlerine göre küçük parçalara bölerek toplumun yalnızca belli bölümlerine odaklanıp odaklanmadıklarını, yani gerçek anlamda bir sosyal ayırımcılık yapıp yapmadıkları da sorgulanmaktadır.
\end{abstract} Reklamları

Anahtar Kelimeler: Reklamlar, Sosyal Medya, Sosyal Ağlar, Çay 


\section{Introduction}

The modern individual tries to stick to more of the thematic and individualized media instead of the traditional "Social Networks" of the past. In the mobilized world of 21 st century the individualized concept of the media tries to establish new cultures and new hobbies. Especially with the impact of the peer culture, everybody is under the impact of a friend or a group they establish a network. Thus, the buyers or sellers are more faced to masses than the individuals of the past. In this case, analyzing the reasons and types of decision making is becoming a must for the market owners. Any good or service appearing in the internet area would like to have some statistics to increase the demand and sell better than the others. In some cases, the others might be the local or regional, national or international ones in the same sector. Or it might be possible to argue that similar other sectors could also be accepted as the opponents or competitors. It would be easy to compete if you have no alternatives. Only the well established brands could do it! However, with the age of mobility came the access to all possible markets so that the individuals could put the appropriate products into their baskets even if they live on the other end of the world. It takes only a few more days for the goods to arrive. However, it might not be easy when it comes to the food and food products. Usually these are supposed to be the fresh ones and local markets have more impact on the consumers. Establishing the brand, analyzing the market, clearing the way to reach to the consumers, producers have a long to do list. So, they need to be tempting, alluring and cheap as much as possible. Of course the generations' habits could also be counted on. However, after the baby boomers, the new generations, $X$, $\mathrm{Y}$, and $\mathrm{Z}$ are known to establish their own choices and styles. Each generation had a different value system and standards of living. The younger ones care much more about their health and spend much less for food. Specifically, the ones having a lowest socio-economic status in the society spend more money for the food and beverages without alcohol that is $30 \%$ of their whole income. Yet, the highest social classes spend less money for the same cluster, around $14 \%$ of their income. (TÜIKK 2017) 
Table-1: Types of spending in various income groups

$(\%)$

\begin{tabular}{|c|c|c|c|c|}
\hline \multirow[b]{2}{*}{ Types of Spending } & \multicolumn{2}{|c|}{$\begin{array}{l}\text { The Lowest income groups } \\
\qquad(1 . \% 20)\end{array}$} & \multicolumn{2}{|c|}{$\begin{array}{l}\text { The Lowest income groups } \\
(5 . \% 20)\end{array}$} \\
\hline & 2015 & 2016 & 2015 & 2016 \\
\hline Total & 100,0 & 100,0 & 100,0 & 100,0 \\
\hline Food and Nonalcoholic drinks & 30,2 & 28,9 & 14,6 & 14,2 \\
\hline Alcoholic drinks, Cigarette and Tobacco & 5,0 & 5,2 & 3,2 & 3,3 \\
\hline Clothing and Shoes & 4,3 & 4,6 & 5,6 & 5,5 \\
\hline Housing and Rent & 32,0 & 32,0 & 23,3 & 21,7 \\
\hline Furniture and Homestuff & 5,7 & 5,6 & 6,2 & 6,5 \\
\hline Health & 2,0 & 2,1 & 2,1 & 2,1 \\
\hline Transportation & 8,2 & 8,9 & 21 & 22,8 \\
\hline Communication & 3,0 & 2,9 & 3,6 & 3,7 \\
\hline Entertainment and Culture & 1,8 & 1,7 & 3,8 & 3,6 \\
\hline Education Services & 0,4 & 0,6 & 3,9 & 4,1 \\
\hline Restaurant and Hotels & 4,1 & 4,6 & 7,5 & 7,6 \\
\hline Various Goods and Services & 3,4 & 3,0 & 5,3 & 5,0 \\
\hline
\end{tabular}

The values in the table may not show the total amount because of rounding

Media, having an access to all the individuals and groups, tend to modify them in the way to be consumed and followed the best possible way. For example they ask a question such as "What Women Want?" and they try to answer this question instead of women. Or they formulate something and ask again "What Does the Society Want?" to be formulated in the way the media conducts. Like these, there might be very tiny tricks and intelligent implementations into the life of the individuals that the media directs their way of life as well as expectations, life style or consumption habits. Via the voicing famous consultants, doctors and specialists, they tend to attract the attention of the viewers as to convince them to challenge new routes as to mobilize millions of people to act in a similar way. One of them surely depends upon establishing new the consumption behaviors aiming to canalize the diets, eating habits. Conglomerating with the food sector, it might be interesting to see that almost one of the two commercials belong to the food sector. Even if most of the eating disorders are attributed to the media consumption habits in the past, no conducted study yet appeared regarding the new media. Neither the new media nor social media using habits are blamed for that yet. Yet, anybody could easily put forward that social media has even a deeper impact on the individuals, groups and societies. However, there is certain evidence that these mean divide the societies into smaller groups as to manage them both providing a tailored and rapid flow of information. It is also possible to see how the traditional media rules are broken or underestimated when it comes to private-like conversations in more individualized settings. The social media is making use of more visuals, viral ads, emphasizing the social classes in a diverse and mocking way within the traditional society. Usually 
accompanied by the humor factor, these commercials tend to be followed and forwarded frequently, liked and adored and even commented. Using the well-known artists the products depicted are welcomed most warmly and in an innocent way. The tea commercials in this respect are easily reached, effective and seem to be successful in first sight. Due to the close connection with the product for centuries, tea was not named under different brands and kinds up to the recent years. This was also through the effect of the 'outcomers', in other words, coffee brands visiting the country in the last decade.

\section{Aim and Methodology}

Trying to be the representative of the past and the old traditions, tea became somewhat 'different' in the new era as to depend on the different types of customers and producers. Being one of the oldest friends of the human being the tea leaves help people share their fun and sorrow over a cup of tea. Yet, in the last decade, checked in the google for example one could reach around 750 thousand visuals regarding tea. Aiming to analyze the concept of tea in the past and present society, the paper follows both qualitative and quantitative research methodology concentrating more on the positioning of the product as a sign of social class. The collected data involving new media samples of the last five years, the paper aims to first classify the ads into prominent groups and second provide both a content analysis as well as a discourse analysis of each. The paper questions if the ads refer to tea consumption at different levels of human needs and if the social settings in tea ads refer to different social classes. The paper is also questioning if these tea brands, concentrate mainly on different clusters of the society, dividing them into smaller chunks ending up with the consumption of different types of products and diets. Regarding the ethical point of view, if there's something wrong on the way they position the product and the consumer, it would be necessary to consider results.

\section{Findings and Interpretation}

Consumption is consuming the food and goods. Yet, the individual consumption would not mean that much specifically in the modern world. That's why the family and the similar type of families are questioned on their consumption habits. Or perhaps similar tendencies of the same age groups could be questioned in its wider sense. Consumption; is the consumption of goods produced or received to meet people's needs and desires. Consumption is the last objective of all economic activities. Expenditure is all the expenses (money) or sacrifices that are spent to buy a good or service. Expenditure for a purchased good is defined as expenditure, consumption as consumption of the purchased good by the household in some way. For example; whereas the money that the household pays for 3 kilograms of tea 
bought from the supermarket is expenditure; the consumption of $1 \mathrm{~kg}$ of this tea is accepted as consumption. (TUIK 2008:14)

Trying to be the representative of the past and the old traditions, tea became somewhat 'different' in the new era as to depend on the different types of customers and producers. Being one of the oldest friends of the human being the tea leaves help people share their fun and sorrow over a cup of tea. Yet, in the last decade, checked in the google for example one could reach around 750 thousand visuals regarding tea. Tea cultivation was possible only after getting Batum back by 1917 . The committee visiting those areas provided a report on what to grow in those humid fields. The committee also mentions the first attempts and failure of 1833 growing tea in Russia planting China, India, Japan or Ceylon tea. Yet the committee aims to bring around 6000 tea plants and a few hundreds of tea seeds from Tiflis. And this time it was successful. Tea cultivation in Turkey was initiated in the early years of the republic in order to create a source of livelihood for the people living in the Eastern Black Sea region and to meet the tea demand of the country. The process started with the law numbered 407 issued in 1924, has been the most basic means of subsistence and employment potential of the region with the support of the state for many years. According to the data from the Ministry of Food, Agriculture and Livestock, in 836 thousand acres of tea in the Eastern Black Sea Region of Turkey, around 212 thousand producers of tea producers are engaged in agriculture. Regarding the tea production of Turkey after 1950's, specifically between 19672011 we see a continuous increase. This is not only due to the increase of the number of the tea growers specifically in the last two decades but also due to the betterment of the products. The tea growers reached up to 205.312 people each having a part of the soil and bank credits as well as the government support for their products. Due to their special position in Turkey their social respect and credibility is also very high.

Table-2: Tea Production in Turkey between 1967-2011

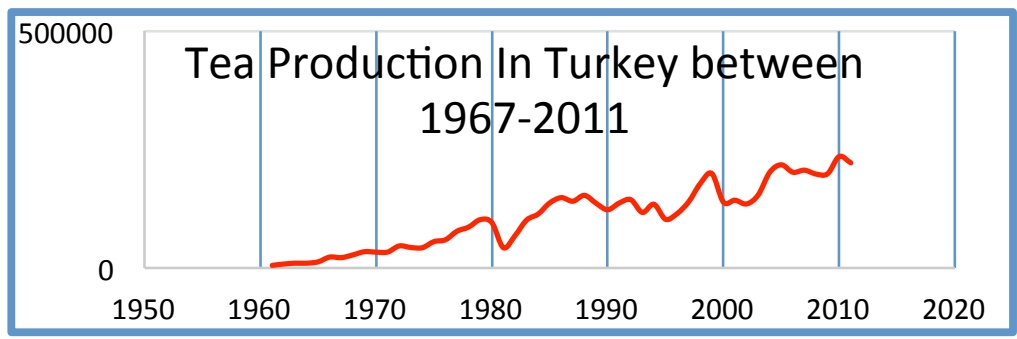


Regarding the depicted meanings of food, whatever the rulers impose, in most cultures, the food is associated with different types of mood or being. The grapes for example are for joy and celebration, walnut is for brain activity, chocolate is for depression, milk is for good sleep, etc. Exhilarating substances are mainly summed up as tea, coffee and tobacco. (Pembecioğlu and Akgün Çomak 2014:220) Regarding the Turkish society in the past, having a cup of soup in the morning, now changed a lot in habits and traditions. Instead of using homemade nutritious goods the growing tendencies for coffee from Brazil or Vietnam sound interesting. The role of media in this process is more than anything else. Especially, the notion of "tea - coffee break" took place in the daily conversations and programming. How could one know that first promoted in 1952 tea could mean a lot to the working class in today's world? This notion also brought the concepts such as better facilities to brew coffee or tea, fast food and more than anything else, instant tea, coffee and vending machines. This also brought the idea of establishing separate places called as coffee houses for short meetings or breaks. (Pembecioğlu and Akgün Çomak 2014:221)

Tea production is one of the main production types regarding the Black Sea Region. In Turkey, annual wet tea yield can range from 1,250 to 1,350 thousand tons depending on climate of the year and agricultural technical precautions. Today, followed by Vietnam, Turkey is the fifth in the World to grow tea after China, India, Kenya, and Sri Lanka.

Table-3: Tea Growing Countries

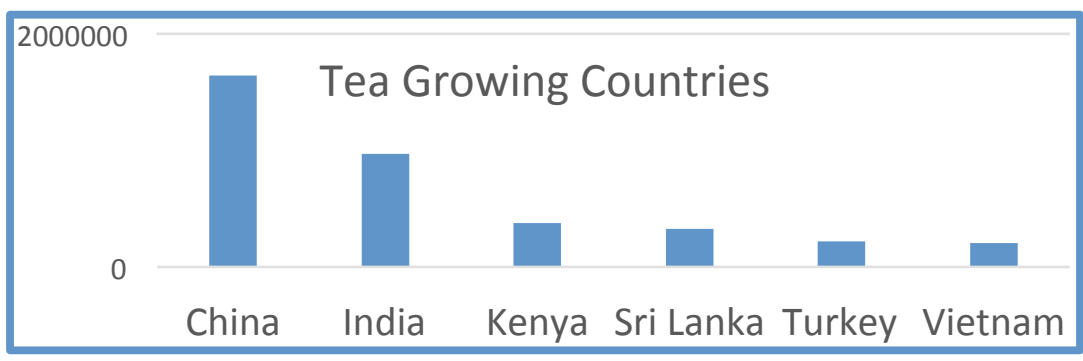

Tea is grown in more than 30 countries around the world. Turkey is in the 8th row among tea producer countries in the world in terms of the breadth of tea farming areas. It is also the 5th in terms of dry tea production and 4th in terms of annual per capita consumption. It is estimated that around 240 million cups of tea are consumed daily in Turkey. Depending on the statistics, the world tea market in 2014 is around 18 billion dollars. $97 \%$ of the world tea consumption is black tea, $3 \%$ is made of 
green tea. Tea cultivation is carried out in the Eastern Black Sea Region within the borders of Rize, Trabzon, Artvin and Giresun provinces. Tea production is in the same illusions in the industry. Today, a total of 762,412 decares of land is farmed with 205,000 tea farmers. Every year, between 1 million 200,000 and 1 million 300 thousand tons of fresh tea leaves are harvested in the region. Approximately $220,000-230,000$ tons of dry tea is produced from this amount of tea leaf.

Both private and public tea companies are active in the tea sector. The production and packaging activities of private entrepreneurs in the sector started with the Tea Law No. 3092 published in 1984. With this law, the state monopoly of the tea was removed and tea cultivation, production, processing and sale were released. The share of both sectors in production has approached each other over the years. At the beginning, the public share, which is $95-100 \%$, fell to $50-55 \%$ when we arrived in 2016.

681,000 tons of fresh tea leaves harvested in 2015 were purchased by Çaykur and the remaining 637,000 tons of tea were purchased by private sector firms. Çaykur processes the age-old tea leaf it bought today in 47 factories. There are 150 private factories in the region. $652 \%$ of 762 thousand acres of agricultural land is in Rize, $21 \%$ in Trabzon, $11 \%$ in Artvin and 3\% in Giresun provinces. Tea agriculture is still being carried out in the form of small family farming. Tea producers have tea garden under 5 decares, $20 \%$ to $5-10$ decares, $3 \%$ to $10-20$ decares, $01 \%$ to 20 decares tea garden. $98 \%$ of agricultural incomes in Rize, 27\% in Artvin, 25\% in Trabzon are obtained from tea agriculture.

Whereas the tea prices are somewhat free from monopoly and the producers are allowed to sell the products to the government based institutions or the free market. Tea import is also free in Turkey. However, $145 \%$ customs duty is applied to tea imports. According to the Customs Union Agreement with the EU countries, 200 tons of tea can be imported from EU every year having a 45\% customs tax.

The price of wet tea increased by $12 \%$ compared to the previous year and was 1,77 TL. (TÜİK 2017) Turkish people paid around 271.090 TL for coffee, tea, mate and spices just last year.

Down below the types of the tea products and how much money is spent on them last year is summarized. Information into this table is based on data gathered from the yearly Household Budget Survey (HBS) which has been carried out by Turkish Statistical Institute since 2002 regularly. The survey is one of the important data sources which are used for getting information on socio-economic structures, 
levels and consumption patterns of the households, and for determining the needs of the society and testing the validity of the applied socio-economic policies.

With the impact of the media, new tea types are appearing and these new types bring up new types of consumption as well as new media literacies. Since, each generation has a different way to follow the media, the new generation makes it possible to follow what they really want and help people to see what their choices are. Regarding this challenge one should not forget that specifically Turkish families spend most of their budget for food and non-alcoholic beverages. The others follow in the following order as alcoholic beverages, cigarette and tobacco, clothing and footwear, housing and rent, furniture, houses appliances \& home care services, health, transportation, communication, entertainment and culture, educational services, restaurant and hotels, various good and services.

Depending upon the type of the product, mainly tea could be found in different ways in the last two decades. The healthy nutritious style is much more emphasized than ever through the transmedia messages. The groups and networks were established as a strong tie among the $\mathrm{x}$ generation now reaching to their golden age. The recipes of happiness or fitness would be rounded around the different media. With the impact of all these messages and new appearing goods a new market was established. The varied products now accessed through the wider markets with their varied and shiny packaging as well as through the internet connections. The healthy meals are accompanied through the healthy beverages. Hereby the audience was also testing the new life style just as the previous generations experienced through Great Gatsby and blockbuster marketing strategies of the Jazz Age.

Regarding the tea expenses of the country reaching up to $84652246 \mathrm{TL}$ annually, local tea in the form of the packages takes the first place. (See Table-4) Either in the form of packs or open way the local tea covers the $76 \%$ of the whole tea expenses. The imported tea also has an important place in the society. Even if the taxes make it harder to buy it, either in its open forms or in package forms, the whole consumption of the imported tea comes in the second row with its $17 \%$ of market share. The "New Tea" on the other hand, reaches up to only a 7\% market share. The main thing here is that these new types of teas could only be found in its sachet forms and they have many different types ranging from daisy, fennel, sage, rosehip to linden and green tea. These new type of fruit teas covering more and more space in the market places still do not have not much of the budget spared for the tea. 
Table-4: Types of drinks and amounts of spending

\begin{tabular}{|c|c|c|}
\hline Type of the Product & TL Spent & Percentage \\
\hline Daisy (Brewing) & 320 & 0,000378 \\
\hline Fennel (Brewing) & 8814 & 0,010412 \\
\hline Fruit Flavored Black Tea & 10342 & 0,012217 \\
\hline Sage (Brewing) & 25171 & 0,029735 \\
\hline Other Plants and Fruit Teas Other & 31515 & 0,037229 \\
\hline Rosehip (Brewing) & 33362 & 0,039411 \\
\hline Plant and Fruit Tea (Bag) for Baby and Children & 39650 & 0,046839 \\
\hline $\begin{array}{c}\text { Sachet Plant and Fruit Tea Other (Cough, Constipation etc. Excluding Health } \\
\text { Purposes) }\end{array}$ & 63829 & 0,075401 \\
\hline Tea Other & 67555 & 0,079803 \\
\hline Mixed Plant Tea (Bag) (Cough, Constipation etc. Excluding Health Purposes) & 89673 & 0,105931 \\
\hline Green Tea & 113685 & 0,134296 \\
\hline Fruit Tea (Apple, Orange, Blackberry, Rosehip etc.) (Bag) & 140604 & 0,166096 \\
\hline Linden & 259274 & 0,306282 \\
\hline Plant Stream (Sage, Mint, Fennel, Daisy, etc.) (Bag) & 535656 & 0,632772 \\
\hline Tea with Fragrant Tea (Bud, etc.) & 604111 & 0,713639 \\
\hline Tea Teapot Bag & 693406 & 0,819123 \\
\hline Imported Tea (Package) & 1452467 & 1,715805 \\
\hline Tea Bag & 1522624 & 1,798681 \\
\hline Tea Indigenous (Open) & 1556927 & 1,839204 \\
\hline Imported Tea (Open) & 12731424 & 15,03968 \\
\hline Tea Local (Package) & 64671834 & 76,39707 \\
\hline Ice Tea Market & 181708 & \\
\hline
\end{tabular}


In this context, tea, food and non-alcoholic beverages are included in the family expenditure group. (See Table-5)(TUIK 2008:20) What is the content of the food basket, which is the basis of the hunger limit in the calculations of TUIK? Tea was included into the food basket as a part of the basics. (TUIK 2008:36)

Table-5: Food and non-alcoholic beverages

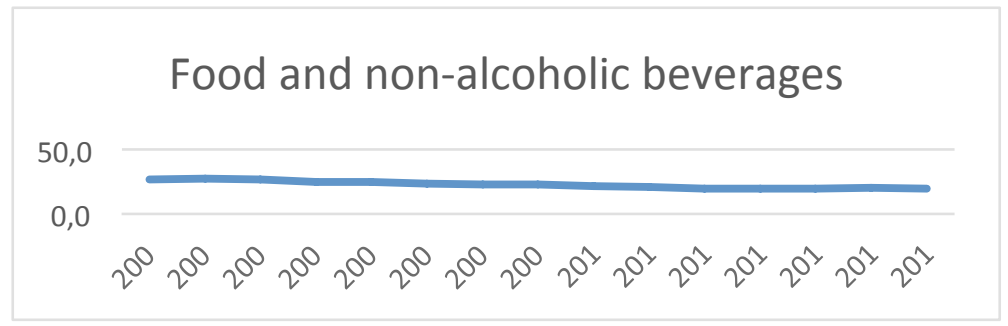

\section{Conclusion}

Tea is a product that its product life cycle never declines, specifically for the Turkish society giving much more importance to that. That means any brand might appear and join the competition assuming to be different and unique and claim more share in the market defeating the previous ones. It adds more competitive character to the tea labels and the brands are really in competition with each other even if the market seems to be silent and in balance. The new brands appear with new dimensions assuming to bring more joy or happiness for the consumers. Some prefer the open tea as in the old days and some prefer the modernized approach in its sachet forms but each one is appealing a different type of audience. When we add more meaning to the product, we also come across with more than the brands. As to Heider \& Simmel experiment in 1944 people tend to attribute meanings to the things around them, people attribute different meanings and concepts to the tea as the product. Some attribute health, some wealth, some happiness and some modernity. In each of these attributions, there appear the images convincing enough to make it believable.

The ads aiming to introduce or sell tea have interesting factors in them. Mostly they are concentrating on the concept of tea as the traditional and national beverage rather than competing with their rivals. Some of them mainly prefer to emphasize the locality of the product whereas the others put forward the world wide known foreign brand. Not only the product itself but also the way it's been introduced to the audience becomes important. Because it's not only the tea but also the peripheral meanings involved. The local and traditional tea advertising more 
than the others gets the most of the market share. The other 'new tea' types have few ads that keep the audience aware of their presence.

The tea could be the same product but at the end, the ads refer to different types of audience. Once classified as the top of the cream, with the lower high layer, altogether reaching to a rate of $5,6 \%$ of the whole population, the highest layer having only $2,2 \%$ of the population has a share of $28,7 \%$ of the whole income of the country. The middle class establishing the $30 \%$ of the population could have only a $42,4 \%$ share of the income whereas the lower middle class has a share of $23,3 \%$ of it with its $34,5 \%$ of the whole population. The lowest layer having the least share of the income with only $5,6 \%$ is the bottom layer with a $29,8 \%$ share of the population. So, selling these different layers, the tea brands develop different strategies for different clusters of the society.

The other factor is targeting the different types of generations and creating strategies for each different type of generation. Having a baby boomers generation as the oldest ones, followed by $\mathrm{X}$ generation being in their mid-fifties and $\mathrm{Y}$ generation in their thirties at most, Generation $\mathrm{Z}$ is the youngest ones perhaps least interested in tea due to the growing coffee market.

The innovations appeal people as well but how can a centuries old plant are innovative as to appeal to billions of people? The answer actually comes through the ads appealing to people of innovation actually establishing only $2,5 \%$ of the population. The first group following it would be a group of $13,5 \%$ of the early adopters.. Equal to each other with a $34 \%$ both the early majority and late majority would take place even if the most traditional ones resisting to the innovations with a $16 \%$ of laggards.(See Table-6 from (http://sphweb.bumc.bu.edu/otlt/MPHModules/SB/BehavioralChangeTheories/BehavioralChangeTheories4.html)

Table-6: The Established Adopter Categories in Diffusion of Innovation Theory

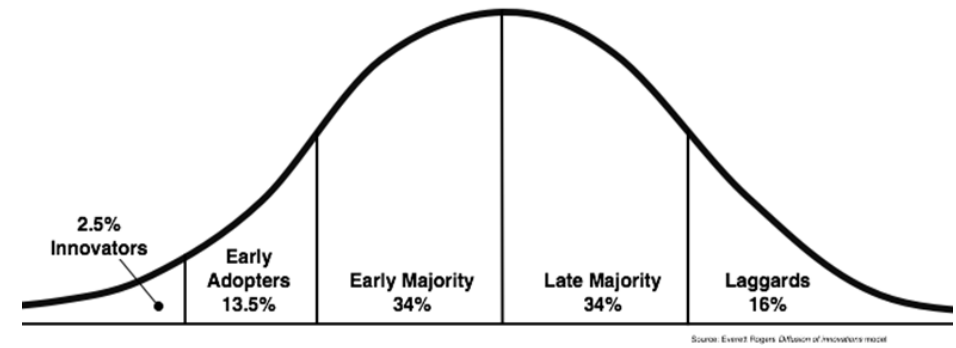


Regarding the mostly consumed brands and their media appearances on television channels and internet, social media one might come across as many different products. In most of these tea examples, famous people accompany these advertisements and emphasize the importance of tea as well as the delicious taste they might have. One of the old fashioned tea advertisements for example make use of Müslüm Gürses five times. The traditional approach to tea and the tea culture appeared as in the form of the certain social class positioning him as the "razor blade", father of the youth, splitting you into pieces as the king of arabesque. The follow up of similar traditional part of tea advertisements could be found in its new form of Şevket Çoruh ads. A well-known character of the famous television serial called "Back Streets" Şevket Çoruh, acts as a roughneck, macho man who could also be as kind as to brew tea and serve it with his own hands to his beloved whereas Ozan Güven another well-known actor acts as cute, polite, top quality gentlemen, serving Lipton tea. In this triangle one is the laggards referring to the slow motion innovations, the other one is referring to the late majority whereas the latest one refers to the innovators.

Apart from the older versions of the traditional characterization of Müslüm Gürses up to the level of talking in English with a tourist visiting Turkey and admiring Turkish tea, reminding us now the more positive days of EU membership hopes, Şevket Çoruh stands for the traditional side specifically regarding the tough male role. His character is not only specifically created character as Müslüm Gürses acted in general, but a designed one for a television serial. Even if the people find it a bit too much regarding his limits and more cold attitudes, the audience is well aware of his warm heart behind the scene. With this character the local tea refers to the general audience, more in a common way, without putting them into Cinderella Shoes or going to a ball situation, living something special, instead the ad puts the audience into regular pairs of shoes having the comfort of a warm house and trustable man.

For the early adopters, there seems to be one other group of ads targeting the women especially. In these ads, the tea is introduced as the common and traditional but somehow new and tasty. The other local tea brands try to convey the message in other settings such as Doğuş tea making use of the famous Berrak Tüzünataç and mainly concentrating on her name Berrak, meaning "Clear" to refer to the quality of the tea. Apart from this humorous riddle or game of word making you smile, the film of Two Derya's have more impact on the concept of traditional tea. Derya Baykal as the beloved and experienced television presenter of the women programs is taking her place in front of the camera with her daughter Derya Şensoy. The top secrets of brewing the most delicious tea are delivered from the mother to the 
daughter. Thus, the tradition of the past is made available to the present generation to keep on carrying them to the next generations. The sincere talks between the two generations aim to capture the attention of the two different age groups as well as the decision makers of the families as the females. In this case, having the Turkish brand Doğuş, appeared in the marketplace as the traditional tea having a modern look with its sachet and bergamot-flavored forms.

Even if the two advertisements refer to the same type of traditional tea, one of them "Lipton" is looked as the foreign brand and imported tea referring to the higher social class due to the bergamot flavor. Thus, it's been positioned as the product to refer to the higher class. Even if these two ads seem to be referring to different social status people and different economic classes, in both advertisements similar life styles are used. When for example the female calls up her beloved husband having a rest in hammock in the green field of a luxurious house, she feels a bit in a hurry to welcome their best friends about to visit them. The lady in her best white clothes as the symbol of purity and richness gets ready for the upcoming visitors, brewing the most delicious tea for them. As the representatives of a well off family, they want to welcome their guests in the best possible way, offering them the best tea ever: Lipton Black Pearl. Regarding the background symbols, all these happen while the audience gaze the white washed walls, beautiful kitchen design, new types of tea brewing using the glass teapot and new form of tea glasses in the form of tulips. The red color is used via the tulips in the garden to associate the color of a specially brewed tea. In these ads, the people are happy with their tea glasses in their hands and Lipton, as a foreign branded tea is introduced to Turkish people as a special blended tea form to make use of the high socio-economic class audiences. In fact the ad stands for the reproduction of the ideals, positioning the women and men in the ideal forms and places. This idealization of the young couple and their life cluster serves to trigger the audience as to help them to make up their own ideals as well. For most of the viewers, this kind of a life is just a dream and not easily accessible. The garden, the hammock, the kitchen, the friendship atmosphere, the luxury of life, etc. Yet, the tea is available in the markets as a relief or replacement of the feelings of peace and happiness experienced in such an atmosphere. That's why the audience is somewhat conditioned to get whatever they can out of the advertisement. In this case, the accessible thing is only the tea! This approach could explain us why the foreign branded tea, Lipton is selling more than the local tea brands as the expression of the desires and life styles so longed for.

Having a general tone of voice and the local accent, the middle aged women inventing Didi, aunt Naciye, in her original style is starring the ice tea ads making it more accessible and acceptable for the Turkish audience and consumers. Having its roots not more than two decades, ice tea appeared in the beverages field and gained 
most of the market share in a short time. The ice tea concept is much more carried with the pop start images such as Ceza or Hayko Cepkin appearing in more localized atmospheres in an appreciated way. These kind of marketing strategies appealing to the $\mathrm{Z}$ generation pays even higher in such a short run reaching an expenditure of up to $181708 \mathrm{TL}$ just last year.

In most cases the tea is positioned as a very special product in each ad. Tasting it mostly expanded to smiles, body language, happiness, etc. Apart from that, in most of the ads the product is associated with femininity, tea is attributed several values such as luxury, modernity, excellence, dignity, nature, kindness, beauty, sex appeal, etc. The audience research or audience measurement techniques could also be valid in tea ads. Because, these five classes of people could also be seen in the ads. The segments such as A/B, C1, C2, D/E could also be seen in the context and content of the ads in the forms of different social classes. The depicted family settings provide friends more than the family members.

In conclusion, the collected data involving new media samples of the last five years prove that the tea advertisements refer to tea consumption at different levels of human needs and the social settings in tea ads refer to different social classes. Apart from that, it is quite certain that questioning these tea brands and advertisements each concentrating mainly on different clusters of the society, the ads divide the social structure into smaller chunks ending up with the consumption of different types of products and diets as if they are somewhat totally different from each other. Regarding the ethical point of view, the audience and the auditors never notice anything is wrong about the way they position the product and the consumer since they never see the big picture but consider the details of the each product.

\section{References}

-Akgün Çomak N., Pembecioğlu E.N.,(2014) "Changing The Values Of The Past To Future ", 3rd Annual International Conference On Journalism \& Mass Communications (JMComm 2014), Singapur, SİNGAPUR, 22-23 Eylül 2014, vol.1, pp.219-227

-Barış Manço Lipton Çay içince ben reklamı (2016, May 25). Retrieved from https://www.youtube.com/watch?v=FZfmv3Gd81M (Lipton-2016)

$\begin{array}{llllll}\text {-Beta } & \text { Tea } \quad(2017, \quad \text { November } & \text { Retrieved from }\end{array}$ http://www.caydukkani.com/markalar/beta-tea/

-Beta Tea Çay yaprak (2014, August 15). Retrieved from https://vimeo.com/103517112 (Beta Tea-2015)

-Bi Çay daha Türkiye (2016, January 4). Retrieved from https://www.youtube.com/watch?v=23KxVZGowkk (Lipton-Bi Çay Daha Türkiye-2016) 
-Ceza Didi reklamı- Acaba ne içeyim yanında yemeğin (2015, May 21). Retrieved from https://www.youtube.com/watch?v=B-Xt_xf3ZNs (Didi-Ceza ve Naciye Teyze-2015)

-Çay Raporu 2015, Çay 1 milyon insanın geçimini sağlamaktadır (2016 April 15). Retrieved from (http://www.zmo.org.tr/genel/bizden_detay.php?kod=25738\&tipi=38\&sube=0)

-Çay Yoksa - Çaykur'un çaysız olmaz dedirten reklamı (2016, March 4). Retrieved from http://alkislarlayasiyorum.com/icerik/296305/cay-yoksa-caykurun-caysiz-olmaz-dedirtenreklami (Gizli çekim reklam)

-Çaykur 2012 Ramazan reklamı (2012, July 20). Retrieved from https://www.youtube.com/watch?v=sYEcgHRhBZ8 (Çaykur-Müslüm Gürses-2012)

-Çaykur Rize Turist reklamı (2012, November 15). Retrieved from https://www.youtube.com/watch?v=1P5Pko4j6qA (Çaykur-Müslüm Gürses-2012)

-Çaykur Çayla markasıla çay evi zinciri kuruyor (2016, April 29). Retrieved from https://www.youtube.com/watch?v=WVK-U9BZ3tk (Çaykur-2016)

-Çaykur Yeşilçam reklamı (2016, April 11). Retrieved from https://www.youtube.com/watch?v=6uOVQBmJ8so (Çaykur-2016)

-Çaykur Tiryaki Çayı Müslüm Gürses (2013, October 24). Retrieved from https://www.youtube.com/watch?v=Z81L75EKWbA (Çaykur-Müslüm Gürses-2013)

-Derya Baykal ve Derya Şensoy Doğuş Filiz Çay Reklamı (2014, September 2). Retrieved from https://www.youtube.com/watch?v=jAhaKTaxkL4 (DeryaBaykal-Derya Şensoy-2014)

-Didi soğuk çay kış reklamları (2017, January 27). Retrieved from https://www.youtube.com/watch?v=TsyPuZdtUOcn (Didi-2017)

-Diffusion of Innovation Theory (2016, April 28) Retrieved from (http://sphweb.bumc.bu.edu/otlt/MPH-

Modules/SB/BehavioralChangeTheories/BehavioralChangeTheories4.html)

-Doğadan çay reklamı -Bu kış sert geçecek-Ofiste (2014, January 12). Retrieved from https://www.youtube.com/watch?v=bgrLUWRhTtQ (Doğadan-2014)

-Doğadan Çay güçlü hisset reklamı (2015, January 6). Retrieved from https://www.youtube.com/watch?v=HpbWAuBZRuo (Doğadan-2015)

-Doğadan Medya (2017, November 22). Retrieved from http://www.dogadan.com.tr/medya.php

-Doğuş Çay- Hüüüp- Derya Baykal (2015, 7 Ekim). Retrieved from https://www.youtube.com/watch?v=FOuM9mngB4w (Derya Baykal-2015)

-Doğuş Çay Berrak Tüzünataç en berrak çay reklamı (2015, October 12). Retrieved from https://www.youtube.com/watch?v=eYzpVcwn4I0 (Doğuş Çay-Berrak Tüzünataç-2015)

-Hayko Cepkin - İftarda Lipton ice tea iç (2016, June 6). Retrieved from https://www.youtube.com/watch?v=1wJKo71H8Z4 (Lipton/Ice Tea-Hayko Cepkin-2016)

-Hayko Cepkin - Lipton ice tea double ice plaj reklamı (2016, July 15). Retrieved from https://www.youtube.com/watch?v=jyZqx0RQfrQ (Lipton/Ice Tea-Hayko Cepkin-2016) 
-Hayko Cepkin Lipton double ice iç (2016, May 26). Retrieved from https://www.youtube.com/watch?v=oNJusOfinZY (Lipton/Ice Tea-Hayko Cepkin-2016)

- Hayko Cepkin düğün stresi bastıysa Lipton iç (2016, April 18). Retrieved from https://www.youtube.com/watch?v=JMQpZ11VWCo (Lipton/Ice Tea-Hayko Cepkin-2016)

-Lipton çay karlı köy yolları (2017, February 15). Retrieved from https://www.youtube.com/watch?v=8Xc4hEV0_iM (Lipton-2017)

-Lipton'dan Dijital Uygulama: Aç Kendini (2014, April 2014). Retrieved from http://www.dijitalajanslar.com/liptondan-dijital-uygulama-ac-kendini/

-Lipton Yellow Label demlik poşet çay yenilendi (2013, July 5). Retrieved from https://www.youtube.com/watch?v=KFKg-ocqDoc (Lipton-2013)

-Lipton bardak poşet çay kampanyası reklam filmi (2012, October 9). Retrieved from https://www.youtube.com/watch?v=5BFTsjmStP4 (Lipton-Ozan Güven-2012)

-Müslüm babalı Çaykur reklamı-2 (2012, June 6). Retrieved from https://www.youtube.com/watch?v=g2t9AqUkKbs (Çaykur-Müslüm Gürses-2012)

-Naciye Teyze ve Çaykur'dan Didi soğuk çay reklamı (2013, July 16). Retrieved from https://www.youtube.com/watch?v=JkIsAp2j21Y (Didi-Naciye Teyze-2013)

-Tolga Sarıtaş Doğuş Çay reklamı (2016, April 22). Retrieved from https://www.youtube.com/watch?v=29mGw7M4-0Q (Doğuş -Soğuk Çay-Tolga Sarıtaş-2016)

-TÜİK(2008).Tüketim Harcamaları, Yoksulluk ve Gelir Dağılımı Sorularla Resmi İstatistikler Dizisi-6. Retrieved from (http://www.tuik.gov.tr/IcerikGetir.do?istab_id=156)

-TÜİK(2017).Turkish Statistical Institute Newsletter (2017, March 6). Retrieved from (http://www.tuik.gov.tr/HbPrint.do?id=24845) 